\title{
MÚSICA E UM POUCO DE SILÊNCIO: DA VOZ AO SUJEITO
}

Carolina Mousquer Lima e Maria Cristina Poli

\author{
Carolina Mousquer Lima \\ Psicóloga, \\ especialista em \\ atendimento \\ clínico com ênfase \\ em Psicanálise \\ pela Clínica de \\ Atendimento \\ Psicológico da \\ UFRGS, mestre em \\ Psicologia Social e \\ Institucional pela \\ UFRGS.
}

Maria Cristina Poli Psicanalista, membro da Appoa professora do Programa de Pósgraduação em Teoria Psicanalítica da UFRJ e do Mestrado Interdisciplinar em Psicanálise, Saúde e Sociedade da Universidade Veiga de Almeida (RJ), pesquisadora do CNPq.
RESUMO: Trata-se de investigar os possíveis efeitos do trabalho com a música na clínica das psicoses. A partir da experiência em distintos espaços clínicos, especialmente em um Centro de Atenção Psicossocial (Caps), as autoras sustentam a hipótese de que a música se mostra uma via potente na criação de intervalos entre o sujeito e o Outro, o que é desafio constante nessa clínica. Dessa análise decanta a questão do silêncio, como elemento essencial na direção do tratamento nas psicoses.

Palavras-chave: Psicanálise, psicoses, música, pulsão invocante.

ABSTRACT: Music and a little bit of silence: from voice to the subject. The article seeks to investigate the possible effects of the work with music in the clinic of the psychoses. From the experience in different clinical spaces, especially in a Caps (Psycho-social Service Center), the authors support the hypothesis of the music like a powerful road in the creation of intervals between the subject and the Other: constant challenge in this clinic. From that analysis upsurges the subject of silence, as an essential element in the direction of the psychoses treatment.

Keywords: Psychoanalysis, psychoses, music, invoking pulsion. 
Son mis voces cantando para que no canten ellos.

(Alejandra Pizarnik)

0 presente relato é composto de associações oriundas da experiência em distintos espaços clínicos, especialmente em um Centro de Atenção Psicossocial (Caps) da cidade de Porto Alegre. Na trilha que abríamos, inquietava-nos o trabalho nas oficinas: espaços que conjugam psicose e os laços que podem ser produzidos a partir da música. Trabalhávamos com oficinas de música, com encontros semanais que reuniam cerca de dez a 15 usuários do serviço, de modo variável.

A proposta de oficina de música se apresentou para nós de modo quase intuitivo, por um gosto compartilhado. Foram importantes também a tradição que esse espaço já gozava dentro do Caps e a necessidade de renovação da equipe. Assim, a partir de nossa inserção nesse espaço, uma série de questões se colocou. A primeira delas, que nos pôs a trabalhar, podemos agora, a posteriori, enunciar na sua forma mais direta: por que abordar a psicose pelo viés da música?

Há uma formulação de Rousseau (1781/1997) na qual transparece o que seria uma linhagem única para três expressões: a voz, o som e a música. O autor propõe uma origem comum para a canção e a palavra. A partir das primeiras vozes teriam se formado os primeiros sons, de acordo com as paixões que os moviam. Enquanto a ira produziria gritos, a ternura daria lugar a uma voz mais doce. Para o autor, "os primeiros discursos constituíram as primeiras canções; as repetições periódicas e medidas do ritmo [...] deram nascimento com a língua, à poesia e à música” (ROUSSEAU, 1781/1997, p.303). Dizer e cantar eram, no princípio, uma única coisa. Assim, uma língua que só possuísse articulações e vozes, uma língua desprovida de melodia, somente seria capaz de transmitir ideias, já que para transmitir sentimentos e imagens seriam necessários o ritmo e os sons. (ROUSSEAU, 1781/1997).

O encontro com essa formulação do filósofo lembrou-nos uma das reuniões da oficina, quando um paciente - que não falava - travou uma espécie de diálogo com um dos oficineiros. Através do som produzido em cada um dos violões - ora o de um, ora o de outro - podíamos distinguir o som de uma pergunta ou de uma exclamação. Talvez isso seja possível na medida em que “toda nossa relação com os universos sonoros e a música passa por certos padrões de pulsação somáticos e psíquicos, com os quais jogamos ao ler o tempo e o som” (WISNIK, 1999, p.19). Portanto, mesmo ali onde não há a palavra falada ou cantada, talvez, ainda assim, haja algo que possa ser lido nessa relação entre o tempo e o som. 
A espera pela próxima nota, pelo que virá a seguir, introduz uma ruptura intrínseca ao tempo musical, que é, antes de tudo, um tempo de escansão, um tempo de movimento. A forma de trabalhar o tempo entre as notas de uma música é o que produz o ritmo. E os tempos do ritmo compõem uma melodia. "A música não se desenvolve como uma linguagem que narra, mas descreve um tremor surdo, a oscilação que antecede a catástrofe” (LAMBOTTE, 1996, p.697). Talvez o interessante da música esteja justamente nessa instabilidade criada pelo jogo entre padrões de recorrência com acidentes que desequilibram. O jogo entre a repetição e o novo cria o "tremor surdo”, essa espera pelo que virá a seguir.

Nesse espaço, portanto, música e clínica se conjugam, demonstrando igualmente quão clínico é o trabalho de uma oficina. Primeiro, porque manter os ouvidos abertos ao próximo acorde abre um espaço de espera pelo Outro. Depois, porque esse espaço de espera é aquilo que, na clínica, resguarda um espaço para o novo. Afinal, o trabalho do analista também é uma lida com as distensões e contrações do tempo. A aposta de quem escuta e daquele que padece é de que, aos poucos, vai ser possível ritmar de outra forma o mesmo e o novo, a repetição e a diferença.

O tempo é o campo da música, pois cada som é determinado pelo número de vibrações do corpo sonoro em um determinado intervalo de tempo. E se a música é feita de tempos, isso significa que, nela, os sons são sempre relativos, ou seja, estão sempre em relação um ao outro. Um som isolado — assim como o significante — não nos diz nada; é sempre grave ou agudo em relação a outro, "porque todas essas propriedades não passam de relações e, podendo o sistema inteiro variar do grave ao agudo, cada som muda de ordem e de lugar dentro do sistema, na medida em que este muda de grau” (ROUSSEAU, 1997, p.320).

Assim, chegamos à seguinte fórmula: a música é um fazer com o tempo. Um fazer que cria uma relação entre as notas, resguardando a temporalidade e garantindo que o pensamento, por meio das imagens, seja acompanhado de movimento. Um fazer que joga com a presença e a ausência de som.

Para Didier-Weill (1998), os jogos de presença e ausência, nos tempos da constituição do sujeito, poderiam ser exprimidos de acordo com uma fórmula: "há” e "não há". Ao infans caberia a tarefa de integrar essas duas mensagens contraditórias, substituindo o "há” ou "não há” por uma "significação terceira propriamente inaudita, que é, quando ela tem êxito, a significação da metáfora paterna" (DIDIER-WEILL, 1998, p.19). Essa nova significação representaria a ausência no seio da presença. A forclusão seria resultante de um processo de constituição no qual o "não há” não se fez acompanhar de um "há”, ou seja, é um "não” absoluto, que não pôde ser relativizado pelo simbólico. Passando à música, o autor nos pergunta se a sucessão diacrônica “há”-"não há” seria aquela 
ouvida no ritmo da música, quando "há” é o som e "não há” é o intervalo entre dois sons.

Tal relação entre a constituição do sujeito e a música parece ser o prefácio de uma pergunta que só no final de outro livro, publicado em 1999, o autor formulará: "os psicanalistas não seriam requisitados a compreender em que reside a eficácia do som musical sobre a forclusão psicotizante?" (DIDIER-WEILL, 1999, p.153). Antes de chegar a esta pergunta, porém, o autor percorre um longo caminho no que diz respeito à transmissão na constituição do sujeito.

Em nosso trabalho na oficina, partimos da suposição de que a música é potencialmente capaz de, através de um arranjo de tempos, produzir um laço entre aqueles que dela compartilham. Assim, talvez essa potência dependa da produção de um tempo consonante entre os sujeitos, um tempo de encontro. "Cantar em conjunto, achar os intervalos musicais que falem como linguagem; afinar as vozes significa entrar em acordo profundo e não visível sobre a intimidade da matéria [...]” (WISNIK, 1999, p.27). Na clínica com pacientes psicóticos, acordar os tempos, não para anular a singularidade, mas de forma a não perder de vista a busca pelo outro, a instituição de um espaço Outro, é um desafio constante. Talvez por isso o violão seja, em nossa experiência na oficina de música do Caps, tão requisitado pelos pacientes. Quando cada um tem seu tempo, o violão funciona diminuindo o "grau de incerteza no universo, porque insemina nele um princípio de ordem temporal” (idem).

\section{DA VOZ AO SUJEITO}

Um artigo originalmente publicado na Revista Silicet, sob o título de "Introdução crítica ao estudo da alucinação” (1968/2003), sustenta que a alucinação inscrevese, por sua natureza, em um campo distinto de outros sintomas, como, por exemplo, o automatismo mental ou a fuga de ideias. A primeira proposição é de que a alucinação seria o sintoma necessário e suficiente do estado psicótico, quando essa se apresenta "sob a forma do desconhecimento: eles me dizem que" (INTRODUÇÃO..., p.44). ${ }^{1}$ Ou seja, quando, em relação à alucinação, o paciente não se encontra em posição de sujeito. É, no entanto, a segunda proposição que nos interessa de forma especial nesse momento. Ela resguarda o caráter sempre verbal e não necessariamente auditivo da alucinação, já que o sujeito pode escutar as vozes sem que, no entanto, um som se produza. Para sustentar essa proposição, o artigo refere que, conforme Lacan:

\footnotetext{
${ }^{1} \mathrm{O}$ artigo, traduzido por Analice Palombini, foi publicado no primeiro volume da Revista Silicet, da Escola Freudiana de Paris. A proposta dessa revista é que os artigos — com exceção daqueles de Lacan - não fossem assinados e que seus autores constassem em uma lista coletiva, como grupo de trabalho.
} 
“[...] o ato de ouvir não é o mesmo, conforme vise à coerência da cadeia verbal, isto é, a sua sobredeterminação a cada instante pelo a posteriori de sua sequência, bem como à suspensão de seu valor, a cada instante, no advento de um sentido sempre pronto a uma remissão, ou conforme se acomode na fala à modulação sonora, a uma dada finalidade de análise acústica: tonal ou fonética, ou até mesmo de potência musical." (LACAN 1957-58/1998, p.538)

Assoun (1999) utiliza-se do mito de Argos, descrito por Ovídio, para nos falar de uma dupla condição da voz: a falada e a tocada. A cabeça de Argos possuía cem olhos, que repousavam por revezamento: a cada turno, alguns olhos descansavam, enquanto outros se mantinham abertos. Argos, portanto, era aquele que não cessava de olhar, o velador perfeito para servir a Juno na tarefa de vigiar todo o tempo à ninfa rival. A pobre ninfa é então vigiada até o momento que perde a voz.

O interessante é que a única maneira de distrair o olhar incorruptível e sempre vigilante de Argos era por meio de uma palavra, uma voz que fizesse dormir de uma vez por todas esse que dormia sempre com um olho aberto. "O que inicia a perda de Argos é a 'harmonia' de uma ária musical, a de 'syrinx', da qual ele quer saber a história. Aí começa o extraordinário combate da voz sedutora e do olhar obstinado” (ASSOUN, 1999, p.14). Argos manteve-se sob o encantamento do contador de histórias Hermes, que, com sua palavra, tentava vencer a vigilância. Por fim, pestanejou o monstro escópico, e Hermes percebeu que todos os olhos estavam fechados. Para assegurar-se do feito, Hermes, já em silêncio, passou sua varinha mágica pelas cem pálpebras e disse: “Argos, eis-te jacente, a luz que animava todos os teus olhares se extinguiu e teus cem olhos estão todos mergulhados na mesma noite". Os cem olhos de Argos renasceram na plumagem dos pavões.

O mito coloca em destaque duas dimensões da voz. Uma que está do lado da musicalidade e que suspende o sentido, a "syrinx" que desperta a curiosidade de Argos. É porque ele quer saber a história de "syrinx”, que começa a escutar a palavra de Hermes: essa outra voz, função de suporte do significante. Duas dimensões que podemos apenas experimentalmente separar, uma vez que são como o direito e o avesso da fita de Moebius.

A suspensão do sentido deixa em relevo a sonoridade da voz, enquanto resto e presença. Resto porque se descola do corpo; presença, porque chega ao ouvido do outro. Na clínica da neurose e com algumas cenas do cotidiano, também testemunhamos uma função da voz. O paciente pede ao analista que fale qualquer coisa, precisa escutar sua voz, precisa saber que o outro está ali. A voz aplaca a angústia do sujeito em desamparo. Através dela faz-se sentir que o Outro ainda está lá. Se no escuro a criança pede que lhe falem é porque a 
voz cria bordas e limites, desenha um contorno imaginário entre eu e Outro, interior e exterior.

Por outro lado, a relevância do sentido deixa em suspenso a materialidade sonora. Não é necessário o som para que a paciente escute as vozes que lhe dizem: "tu vais ser pra sempre sozinha" — voz que chega ao ouvido sem escalas. Não se pode detê-la com facilidade porque não há intervalo entre eu e Outro, interior e exterior. ${ }^{2}$ É uma voz que não se reconhece, não se representa como própria e que, ao mesmo tempo, não se confunde com outros ruídos.

"A voz alucinatória inscreve-se, para o doente, em um registro particular, identificável imediatamente sem nenhuma mediação, e cujas metáforas, citadas na tentativa de especificá-la, culminam na relação enigmática: é um pensamento que se escuta” (INTRODUÇÃO..., 1968/2003, p.47), pensamento que pode exigir do paciente um esforço para lidar com imperativos. Tal esforço requer, muitas vezes, que ele invista todo seu potencial sensorial, de forma a tornar-se cego ou surdo a qualquer outro estímulo que não seja objeto da alucinação. Assim, a partir da voz, toda a existência pode ser suspensa. Em contrapartida, a possibilidade de que a voz se retire pode representar, como no caso Schreber, "a angústia intolerável de um fim do mundo" (Idem, p.50). Assim, ao mesmo tempo que as vozes da alucinação ameaçam a existência do sujeito, a sua presença garante que o mundo siga existindo. Que função pode ser essa de garantia?

Antes de dar lugar a essa pergunta, gostaríamos de ressaltar essa característica da voz, de funcionar ao mesmo tempo como o objeto mais repugnante - do qual o sujeito tenta livrar-se de várias formas, colocando um rádio próximo ao ouvido, por exemplo - e o objeto mais prestigioso - que funciona como garantia de alguma coisa. É desta maneira que o artigo publicado na Silicet situa a voz, como objeto erotômano que ordena "paixões extremas: êxtase e perseguição” (Idem, p.51), chegando a afirmar que "toda alucinação, qualquer que seja sua localização ou o modo de sua expressão, é de natureza genital” (Idem, p.51).

Podemos perceber facilmente a abundância de acusações sexuais e temas obscenos nas alucinações. Em geral, são trazidos pelo paciente de forma crua,

\footnotetext{
${ }^{2}$ Em relação ao intervalo, gostaríamos de incluir aquilo que foi chamado, no artigo "Introdução crítica ao estudo da alucinação", de "natureza do campo espacial induzido pela alucinação" (p.49). Esse seria um traço radicalmente original, induzido pela alucinação, que exigiria o abandono dos conceitos que costumamos utilizar para caracterizar o campo da alucinação na relação com o paciente, como falta de distância ou íntima proximidade, termos da geometria euclidiana. O artigo sugere, retomando um trabalho de difusão restrita ("Da aventura paranoica: o caso Schreber") o termo "fenômeno do muro mediano" (p.49), uma vez que "o imaginário aqui representado do arrombamento ou da fragmentação do campo próprio nos parece diferente daqueles que se poderia evocar a partir da constituição eu/não-eu, dentro/fora [...] Retenhamos [...] a facilidade com que esse fenômeno vem se inscrever sob o modelo da fita de Moebius" (p.50).
} 
não causando um constrangimento perverso, mas uma interpelação por estarem desprovidos de qualquer recheio simbólico. De acordo com o artigo supracitado, as obscenidades e acusações sexuais não seriam reveladoras de uma homossexualidade ainda não revelada ou de uma culpa masturbatória, mas sim de uma determinada posição ocupada pela voz na estrutura, e que levaria o sujeito a estar, ele mesmo, na condição de puro objeto.

Assoun (1999) nos fala de um excesso de voz a que está sujeito o psicótico. Por outro lado, como um reverso, teríamos a falta de voz no sintoma neurótico da afasia. Mesmo diferenciando as vozes da alucinação e a voz do supereu, em voga na neurose obsessiva, o autor retoma o artigo de Freud "Uma experiência religiosa" (1927/1996) para desenvolver o argumento de que as vozes da alucinação funcionariam como uma espécie de reconciliação com o Outro. No relato apresentado por Freud, a voz apareceria em sua dimensão delirante como resposta do Outro, frente à ameaça de vê-lo desabar. A voz seria, assim, uma "via de reparação do Outro” (ASSOUN, 1999, p.138). Encontrando-se ameaçado, a voz surge para assegurar a sua presença.

Parece-nos clara a função de reparação, quando o sujeito neurótico está confrontado pela castração, quando a suposição de "há ao menos um" ameaça cair. Mas, como pensar a reparação do Outro na clínica com a psicose? Na psicose, trata-se da necessidade de produzir uma reparação? Ou seria antes uma vacilação que o psicótico visaria produzir em um Outro tornado absoluto?

Analisando o caso de Schreber, Assoun (1999) aponta que, ali, as vozes que intervêm ordenando a transformação em mulher tiveram um papel fundamental nessa passagem entre um delírio de caráter mais blasfematório para uma espécie de reconciliação. A ordem de transformar-se em mulher seria uma resposta à questão colocada pelo próprio sujeito em nome do Outro. A voz funcionaria como uma espécie de reendereçamento da questão do sujeito. Assim como no caso apresentado por Freud, a voz teria, em Schreber, essa função de reconciliação com o pai, mas a custa do delírio.

Essa voz parasita do próprio corpo é a voz na condição de objeto a. Lacan já havia dado a indicação de que "a voz do Outro deve ser considerada um objeto essencial. Todo analista será incitado a dar-lhe seu lugar e a seguir suas distintas encarnações, seja no campo das psicoses como, no mais extremo normal, na formação do supereu" (LACAN, 1963/2007, p.83). ${ }^{3}$ Diferentemente do campo da neurose, no qual a função da voz operaria mais pela via da montagem do

\footnotetext{
${ }^{3}$ Tradução nossa: "La voz del Otro debe considerarse un objeto esencial. Todo analista será incitado a darle su lugar, y a seguir sus distintas encarnaciones, tanto em el campo de las psicosis como, en lo más extremo del normal, en la formación del superyó”.
} 
supereu, na psicose, embora o sujeito esteja aprisionado no Outro, ele tem o objeto a à sua disposição. Na primeira e última aula do seminário sobre os Nomes-do-Pai, Lacan situa a voz como o objeto caído do Outro, lugar onde o sujeito fala, e nos deixa a seguinte pergunta: “[...] para além desse que fala no lugar do Outro e que é o sujeito, o que há desse cuja voz toma o sujeito cada vez que ele fala?” (Idem, p.84). ${ }^{4}$ Embora o seminário não tenha continuidade, Lacan deixa a indicação de irmos além da questão da voz e de nos guiarmos a partir dos três termos: gozo, desejo e objeto.

Retomando o seminário anterior, veremos que Lacan (1962-63/2005), por situar a angústia enquanto presença do objeto, dedica algumas lições a essa questão. A partir do exemplo do Chofar, esse instrumento da tradição judaica que representa a voz de Deus, o autor introduz a ideia de que aquilo que sustenta o objeto a deve ser desvinculado da fonetização. Ou seja, a voz pode dispensar a linguagem e aparecer no sopro do Chofar.

O interesse pelo instrumento, diz o autor, deve-se ao fato de ele apresentar a voz de uma forma exemplar e demonstrar como ela é potencialmente separável. A pergunta que nos fica é: a separação diz respeito à significação ou é possível que ela se refira ao Outro, enquanto lugar do significante? E por que seria importante essa experimentação da voz sob sua forma separável? Lacan (1962$63 / 2005)$ segue pelo caminho da constituição do sujeito. A questão seria pensar como esse objeto poderia inserir-se nas etapas de emergência e instauração do campo do Outro para o sujeito.

No texto "De uma questão preliminar a todo tratamento possível da psicose" (1957-58/1998), bem como no seminário As psicoses (1955-56/1985), Lacan nos traz o exemplo de uma paciente que escuta a seguinte injúria de seu vizinho: "porca". A jovem paciente, no entanto, lhe diz que pouco antes de ouvir a injúria, havia pensado: "venho do salsicheiro". Para Lacan (1957-58/1998), o ponto crucial é que o sensório, o som, é indiferente na produção de uma cadeia significante. Ou seja, não é a materialidade sonora que está em jogo ou em primeiro plano. Por isso, a psicose nos coloca diante da experiência enigmática da voz em seu estado puro. O substrato orgânico da voz estaria aqui dispensado, e isso não diminuiria a certeza de que essa voz lhe falou. Portanto, independente de seu caráter sensório, o importante é que a cadeia significante impõe-se ao sujeito “em sua dimensão de voz”. Essa dimensão não se confunde com o ruído, embora o "menor ruído, se ele é ritmado, seja suscetível de colocar em marcha a atividade alucinatória” (INTRODUÇÃO..., 1968/2003, p.47). Disso nos deu teste-

\footnotetext{
${ }^{4}$ Tradução nossa: “[...] más allá de esse que habla en el lugar del Outro y que es el sujeto, qué hay de esse cuya voz toma el sujeto cada vez que habla?”.
} 
munho Schreber que, após ouvir ruídos ritmados, reconheceu neles a presença de milagres divinos, cuja intenção era impedir-lhe o sono.

Retomando o que sublinha Lacan, que o orifício auditivo é o único que não se fecha, Caldas (2007) nos lembra que é pela batida de um ritmo não previsível, a que o indivíduo está sujeito, que o Outro deixa o sinal de sua presença e frente à qual irão existir diferentes modos de responder. É através desse refrão que o sujeito encontra as possibilidades de criação do Outro. Esse refrão é constituído de som e silêncio, mas também de palavras. São elas que podem transformar a voz em letra escrita no corpo. E são elas que resguardam a possibilidade de algum traço de sentido a ser compartilhado, a possibilidade de que o som busque pelo outro e se transforme, um dia, em produção simbólica. A voz, enquanto suporte da articulação significante, supõe a busca pelo ouvido do Outro.

Já nos é bastante conhecido o trabalho de Lasnik Penot a respeito da função de convocação que pode ser exercida pela música da voz. A autora identificou na observação de crianças autistas que a voz da mãe não tinha as características prosódicas do "manhês". ${ }^{5}$ Já na observação clínica de Campanário e Pinto (2006), quando se trata de crianças cuja estruturação está se dando pela via da psicose, ao contrário do que acontece com as autistas, haveria um excesso de manhês por parte da mãe. Os autores apresentam o caso de um menino de dois anos, sem sinais de autismo, mas que não conseguia desgrudar-se da mãe. Até os três meses de vida de Lúcio, sua mãe não conseguia tocar ou falar com ele. Tudo o que ela podia fazer era gritar. Aos 18 meses, Lúcio começou a emitir uma espécie de "uivo desesperado". A partir da história desse bebê, os autores formulam a seguinte questão:

“[...] a simples massa sonora inarticulada pode investir libidinalmente a criança? [...] O que pode se inscrever através da modulação da fala, através exatamente dos picos prosódicos, não seria exatamente a falta? O manhês tornaria possível a primeira abertura para a inscrição do nome-do-pai, possibilitando assim a operação da separação?" (CAMPANÁRIO e PINTO, 2006, p.161)

Tais perguntas nos levam a pensar se a música da voz da mãe, com aquilo que carrega de sem sentido, é capaz de abrir uma passagem ao simbólico. Nos caminhos da constituição, nos diz Lacan (1962-63/2005) que a linguagem não é a vocalização. Nem tudo que o sujeito recebe do Outro está sob a forma vocal.

\footnotetext{
${ }^{5} \mathrm{O}$ "manhês" é estudado por linguistas como uma espécie de “dialeto" das mães. É caracterizado por "modificações da voz e da prosódia, por formas melódicas doces, longas, com grandes extensões. O efeito do ritmo da prosódia é amplificado pelas várias repetições" (LASNIK, MAESTRO, MURATORI \& PARLATO, 2005), aparecendo também cortes entre os fragmentos sonoros.
} 
Mas há, segundo o autor, uma ligação mais que acidental entre a linguagem e a sonoridade. Argumentando que nosso ouvido funciona como uma caixa de ressonância, nos diz que a voz não ressoa em um vazio qualquer, mas em um vazio que é o vazio do Outro. Poderíamos, a partir do que elaboramos até o momento, equiparar isso que Lacan chama de vazio do Outro ao silêncio? A voz ressoa no silêncio do Outro?

Lacan (1962-63/2005) segue argumentando que, para que a voz possa responder ao que é dito, é necessário que ela seja incorporada como “a alteridade do que é dito”. É assim que o autor explica a estranheza ao escutarmos nossa voz no gravador. Esse vazio em que ressoa a voz seria o vazio de sua falta de garantia. Destoando das sonoridades, a voz em questão tratar-se-ia de um imperativo e estaria situada do lado da fala e não da música. Pensamos que talvez a diferença entre essa voz que Lacan situa como imperativo e a voz que estaria situada ao lado da música esteja no efeito de convocação do sujeito.

A voz enquanto fala convocaria o sujeito a responder. Já a voz do lado da música convocaria ao gozo do puro objeto. O interessante é que, aparentemente, esse enquadramento da voz cria um tensionamento com tudo o que vínhamos pensando com relação à música. Ela funciona ora como aquilo que faz calar o Outro, ora como aquilo que captura o sujeito no gozo infinito do puro objeto?

Essa questão, fundamental no trabalho com a psicose, não é simples de ser respondida. Talvez ela constitua mesmo o paradoxo que o trabalho com a música apresenta a essa clínica. Para avançarmos nessa direção, façamos um percurso por um operador lacaniano fundamental: a alíngua.

\section{OS PRIMÓRDIOS DA MÚSICA: ALÍNGUA}

Alíngua, conceito tecido por Lacan (1972-73/2006) no seminário Mais, ainda, quando ele revisita a concepção do inconsciente estruturado como linguagem. Sua proposição modifica essa fórmula inicial a partir da ideia de que a linguagem, com valor de código compartilhado, não seria dada de origem, sendo aquilo que se procura saber a respeito da função de alíngua. Ou seja, que a estrutura linguageira deriva de, é constituída e sustentada por alíngua. O inconsciente que daí advém é definido por Lacan como um savoir-faire com alíngua.

Esse novo operador seria efeito do encontro com a língua materna enquanto objeto, constituindo uma experiência anterior à fala articulada (CALDAS, 2007). Os efeitos de alíngua dão testemunho desse saber que escapa ao sujeito. A presença de alíngua tem, portanto, efeito de enigma, pois articula coisas de 
saber que "vão muito além de tudo o que o ser que fala é capaz de enunciar" (LACAN, 1972-73/ 2006, p.168). ${ }^{6}$

Em termos de constituição do sujeito, alíngua, como traço significante, não deixa de ser aquilo que cai do Outro, mas não de um Outro que existe a priori organizado estruturalmente pela linguagem. Trata-se, aí, de um Outro caótico, portador de uma fala que vale pelas ressonâncias que provoca no corpo. O que Lacan chama alíngua são "os aluviões, os depósitos da chuva de significantes que chegam pela língua materna, os objetos de material fônico, plenos de malentendidos e criações singulares" (CALDAS, 2007, p.65). Alíngua, portanto, é isso que, vindo da língua materna, vai se depositar nesse corpo que é puro pulsional do infans, inscrevendo-o na cadeia significante.

"Quando a criança ainda não aprendeu a falar, mas já percebeu que a linguagem
significa, a voz da mãe, com suas melodias e seus toques, é pura música, ou é aquilo
que depois continuaremos para sempre a ouvir na música: uma linguagem em que
se percebe o horizonte de um sentido que no entanto não se discrimina em signos
isolados, mas que só se intui como uma globalidade em perpétuo recuo, não verbal,
intraduzível, mas, à sua maneira transparente” (WISNIK, 1999, p.30)

A música, enquanto uma linguagem que não narra, mas que ressoa no corpo, nos parece ser um caminho possível para compreender a relação primordial do sujeito com o Outro. Para Didier-Weill $(1997,1999)$ a música aproximaria o sujeito do Outro, situando-o como um “bom ouvinte”. Já através da fala, o sujeito e o Outro estariam muito mais próximos do mal-entendido. Deste modo, a música, em sua essência, seria indutora de uma sincronicidade estrutural entre sujeito e Outro, pois assim como não haveria um intervalo entre o instante no qual a música toca e o instante em que o corpo responde a essa música, tampouco haveria uma latência entre o instante no qual o sujeito cantando invoca o Outro e o instante em que ele advém. Assim, a música teria o poder de comemorar um tempo primordial de constituição, quando, antes de receber a palavra, o sujeito ganharia uma base sobre a qual esta se desenvolverá.

Isso que o autor nomeia como base em que pode germinar a palavra seria a inscrição primordial constituída pelo traço unário. Assim como uma nota musical escandida, o infans captaria essa nota na música da voz da mãe muito antes de poder dar sentido aos fonemas. O fenômeno musical, pelo efeito de transcendência que causa no sujeito - isso que sentimos ao sermos tocados, fisgados, por uma música sem, no entanto, poder explicar o porquê — estaria

\footnotetext{
${ }^{6}$ Tradução nossa: "van mucho más allá de todo lo que el ser que habla es capaz de enunciar".
} 
em relação com o traço unário e seus tempos de inscrição e apagamento. Essa relação seria, para o autor, um ponto deixado em aberto na psicanálise, tanto por Freud quanto por Lacan (DIDIER-WEILL, 1997).

Didier-Weill (op. cit.) nos apresenta brevemente alguns estudos de antropólogos contemporâneos para demonstrar como as sociedades "primitivas" conheciam a afinidade estrutural entre o traço unário e a música. O argumento do autor baseia-se no fato de que, nessas sociedades, entendia-se que ouvir determinada música teria o poder de reverter a forclusão do traço unário geradora do delírio.

Em todas essas diferentes sociedades, havia um ponto comum a respeito da crença de que o delírio era uma punição impingida por um deus em razão de o sujeito ter cometido uma falta simbólica maior. Era por intermédio da música que o xamã podia reconhecer qual dos deuses tinha imposto o castigo e a quem, portanto, deveria ser suplicado um novo pacto simbólico que revertesse a punição. O ritual acontecia da seguinte maneira: tocavam-se distintas músicas, cada uma delas carregando a insígnia de um dos deuses; quando ressoava a música do deus responsável pela punição, o sujeito o incorporava, de forma que era possível reconhecê-lo. Assim, através de uma dança incorporada, o sujeito podia reencontrar o deus que, pela ruptura do pacto, fora rejeitado, forcluído. A partir desses elementos, a pergunta que nos faz o autor é a seguinte: "dispõe a música do poder, que a palavra não detém, de criar as condições de um retorno do sujeito ao que tinha sido forcluído?” (DIDIER-WEILL, 1997, p.247). Para o autor, "o poder de reversão da forclusão detido pela música [...] parece, em duas palavras, ligado à possibilidade que ela detém de tornar a pôr em jogo o circuito da pulsão invocante" (DIDIER-WEILL, 1999, p.153).

De acordo com sua formulação, a interpretação teria o poder de dissolver os sintomas neuróticos, mas não o delírio, em razão de o significante forcluído não ser traduzível por outra palavra, não permitindo equívocos como o chiste. Assim, a palavra do analista, dirigida ao inconsciente, não alcançaria esse significante que está no real.

“[...] a música é, precisamente, este significante zero pelo qual é assumido esse excesso de sentido que, não podendo ser assumido pela palavra, condena-a a não poder senão semi-dizer a verdade. Deve-se dizer que a música diz "a” verdade? Não: ela diz somente o real, pelo fato de que ela o leva à existência e, nisso, seu poder é, ao mesmo tempo, superior ao da palavra e menor que o dela" (DIDIERWEILL, 1997, p.248)

É superior à palavra porque coloca o sujeito em consonância com o Outro, mas inferior no que tange à verdade. Nessa linha, a música nos faz ouvir ao mesmo 
tempo a melodia que um pianista, por exemplo, toca com as mãos esquerda e direita. Se ele tocar uma nota errada com uma das mãos, logo perceberá. Diferente disso, na fala, o equívoco pode não ser reconhecido enquanto uma manifestação inconsciente; ou seja, a dissonância, na fala, pode não ser escutada.

A esse respeito, Lacan (1971/2009) nos fala do efeito do uso de um instrumento musical: a divisão do corpo que sua utilização requer. É preciso fazer dois tipos de movimento ao mesmo tempo, o que implica uma ruptura de sinergia.

“A pessoa que me lembrou desse negócio a propósito da flauta também me fez observar que, com respeito ao canto, no qual aparentemente não existe instrumento — é nisso que o canto é particularmente interessante —, também é preciso vocês dividirem o corpo, separarem duas coisas que são totalmente distintas, mas que, de hábito, são absolutamente sinérgicas, a saber, a impostação da voz e a respiração.” (LACAN, 1971/2009, p.65)

A música cria uma tensão justamente por nos permitir ouvir ao mesmo tempo o som da mão esquerda e da mão direita do pianista, como se fossem uma única coisa, como se essa ruptura da sinergia da qual nos fala Lacan não existisse.

\section{DE UM OUTRO AO OUTRO: DE VOLTA ÀS OFICINAS}

De acordo com Cavalcante (apud CAMPANÁRIO e PINTO, 2006), após a fala atribuída, quando a mãe fala como se o bebê estivesse falando, aparecem pausas longas. São essas pausas prolongadas responsáveis por garantir o lugar falante do bebê. Outro que não se cala é Outro a quem não faltam palavras, é um Outro sem faltas. Para que o sujeito possa tomar a palavra e ouvir a si mesmo é preciso que o Outro se cale. É preciso que, em algum momento, dele não nos cheguem respostas. É nessa medida que “[...] a música pode comparecer dando a ouvir uma resposta possível diante do impossível de se obter uma resposta do Outro, e que ela traz, cifradamente, algo sobre a posição singular de um sujeito para com este objeto" (AZEVEDO, 2008, p.4).

O silêncio decanta como ponto essencial do trabalho de dar voz ao sujeito. Para que ele fale desde esse lugar, de sujeito, é necessário que ele possa esquecer a voz do Outro criando aquilo que Vives (2009) aponta como “ponto surdo”. Só nesse ponto surdo é que o sujeito poderá tornar-se falante, esquecendo-se que é receptor do timbre originário. “Ele deve poder ensurdecer-se para o timbre primordial [...] Para se tornar falante, o sujeito deve adquirir uma surdez específica para com este outro que é o real do som musical da voz" (VIVES, 2009, p.336). Para o autor, esse ponto surdo é o que resguarda o sujeito de ser invadido pela voz do Outro. Nossa hipótese, que sustentava o trabalho nas oficinas 
de música, é de que, ainda que esse ponto surdo não tenha se constituído, seja possível, por meio do trabalho com a música, abrir para o sujeito um espaço de esquecimento - um "ponto surdo".

Tal hipótese nasceu da experiência clínica e, ainda mais especificamente, da cena que passamos a relatar. Depois de sair de longo período de internação, Julia começou a participar da oficina de música. Um dilúvio de palavras, um desajuste no tempo - deste modo podemos descrever a imagem. Julia dançava e cantava de maneira frenética em meio à roda, pedia que lhe batessem palmas, falava em um ritmo que sua boca e nossos ouvidos não podiam acompanhar. Ela tampouco podia nos escutar, nada que dizíamos parecia ter efeito. Então, um dos oficineiros inventou uma música e começou a cantá-la: “A Julia não para de falar, não para de falar, não para de falar. A Julia tem coisas a dizer, o que será que a Julia vai contar?". E Julia, por alguns instantes, entrou no ritmo, improvisando: "A Julia quer arranjar um namorado que seja legal e bem tarado".

Julia, até esse momento, falava sem fazer pausas. As palavras nos chegavam emendadas, e o silêncio — se o pensarmos como necessário para construir o ritmo da fala e o sentido das palavras - estava impossibilitado de cumprir sua função. As palavras eram significações que não remetiam a nada, repetiam-se com uma insistência estereotipada, como aquilo que Lacan (1985[1955-56]) chama de estribilho. Essa foi uma das poucas vezes que Julia participou da oficina. Participação suficiente, no entanto, para nos dar testemunho do aprisionamento à palavra do Outro.

No espaço das oficinas aqui relatadas, poderíamos dizer que a música auxiliava na construção ou no resgate de algumas histórias. Esse trabalho era geralmente operado pela letra da música, que funcionava como disparadora de memórias. Ali elas podiam ser compartilhadas, e então encontrávamos como seguir adiante. Um dia, cantamos uma música da banda Legião Urbana ${ }^{7}$ cuja letra dizia assim:

"Quem me dera / Ao menos uma vez / Explicar o que ninguém consegue entender / Que o que aconteceu / Ainda está por vir / E o futuro não é mais / Como era antigamente [...] Quem me dera / Ao menos uma vez / Como a mais bela tribo / Dos mais belos índios / Não ser atacado / Por ser inocente $[\ldots]$ ”

Sabemos que o trabalho de uma análise é permitir que o sujeito narre a sua história de diferentes formas; como dissemos antes, também a música é um fazer com o tempo. A letra desta música nos coloca uma questão. "Que o que aconteceu ainda esteja por vir" nos fala de um tempo em que o acontecido pode acontecer novamente.

\footnotetext{
7 Título da música: Índios (1986). Autoria de Renato Russo.
} 
Na oficina, seguiu-se então uma rica discussão que remeteu à descoberta do Brasil e aos índios que aqui estavam. Para Lia, paciente participante da oficina, a descoberta era falsa, os índios já moravam aqui e os portugueses chegaram "matando todo mundo". Mas, afinal, a descoberta é contada desde um ponto de vista: o dos colonizadores. Para eles, sim, tratava-se de uma descoberta: eles não conheciam o Brasil. Até que chegamos à pergunta: e os índios, vieram de onde?

Mesmo - talvez principalmente — as perguntas que não tinham resposta levavam a outras histórias: o filho que acabou vivendo longe e não temos como encontrar, o que vai acontecer quando morrermos... Foi, inclusive, uma morte que precipitou Lia em uma depressão profunda. Assim como ela quando chegou ao Caps, outros tantos pacientes ali aportavam apartados de suas histórias, como se não tivessem nada a dizer, como turistas sem bagagem. Efeito da medicação? Também, mas não só isso, pois, dependendo do assunto em discussão, ou do ritmo que tocava, algumas fagulhas de sujeito surgiam.

Para alguns, a música — às vezes pela letra, outras vezes com uma lembrança que a melodia evocava — funcionava como disparadora de narrativas, de encontros, de compartilhamentos de histórias. A música operava através da dimensão da palavra. Mas, em outros momentos, ou em especial para alguns pacientes, era algo anterior à palavra que a música operava: era a dimensão espaço-temporal do corpo que a música colocava em questão.

Renato era um paciente que participava da oficina de uma forma muito particular. Entrava na sala, fazia perguntas: "né que ser bonito é ser inteligente? O que é uma pessoa inteligente? Quer ver como o homem é imortal?”. Em seguida, saía da sala, pois não conseguia permanecer no mesmo lugar por muito tempo. Além disso, a sua necessidade de falar e de ser escutado não o permitia esperar que os outros terminassem de falar, o que irritava alguns companheiros de oficina. Quando cantava alguma música, acabava “atropelando” o violão, a não ser que alguém o acompanhasse batendo com as mãos em suas costas no ritmo da música. Era preciso que a marcação do tempo da música fosse feita diretamente no corpo. Poderíamos dizer que, ressalvadas algumas diferenças, para Renato, assim como para Julia, era difícil “entrar no compasso”. Eles habitavam e eram habitados por um outro tempo. Seria este um tempo característico do não fechamento do circuito pulsional e que a música teria efeito de recompor?

Se dissemos que era preciso calar o Outro — no sentido de que ao Outro é preciso que falte palavra — é porque falávamos de um Outro que fala pelo sujeito, no lugar do sujeito, excluindo-o do lugar da enunciação. Por fim, resta também uma aposta: de que a música pode produzir um silêncio — ou seria mais preciso dizer um esquecimento? — para que o Outro possa falar nele, no sujeito.

Recebido em 27/7/2010. Aprovado em 2/3/2011. 


\section{Referências}

ASSOUN, P. L. (1999). O olhar e a voz: lições psicanalíticas sobre o olhar e a voz. Rio de Janeiro: Companhia de Freud.

AZEVEDO, R. M. (2008). A voz como objeto a e a separação do sujeito frente ao Outro, III Congresso Internacional de Psicopatologia Fundamental $e$ IX Congresso Brasileiro de Psicopatologia Fundamental. Acesso em 5/2/2010. Disponível em: http://www.fundamentalpsychopathology.org/8_ cong_anais/MR_342c.pdf.

CALDAS, H. (2007). Da voz à escrita: clínica psicanalítica e literatura. Rio de Janeiro: Contra Capa.

CAMPANARIO, I. S.; PINTO, J. M. (2006) “O atendimento psicanalítico do bebê com risco de autismo e de outras graves psicopatologias: uma clínica da antecipação do sujeito”. Estilos da Clínica, v.XI, n.21, p.150-169.

DIDIER-WEILL, A. (1997). “O artista e o psicanalista questionados um pelo outro", in Nota Azul: Freud, Lacan e a Arte. Rio de Janeiro: Contra Capa, p.19-35.

Capa. (1999). Invocações: Dionísio, Moisés, São Paulo e Freud. Rio de Janeiro: Companhia de Freud.

FREUD, S. (1927/1996). "Uma experiência religiosa”, in Obras completas, v.XXI. Rio de Janeiro: Imago, p.175-180.

INTRODUÇÃO CRÍTICA AO ESTUDO DA ALUCINAÇÃO (1968/2003). Correio da Associação Psicanalítica de Porto Alegre, n. 111, p.38-52.

LACAN, J. (1955-56/1985). O Seminário, Livro 3: as psicoses. Rio de Janeiro: Jorge Zahar.

(1957-58/1998). "De uma questão preliminar a todo tratamento possível da psicose”, in Escritos. Rio de Janeiro: Jorge Zahar.

. (1962-1963/2005). O Seminário, Livro 10: a angústia. Rio de Janeiro: Jorge Zahar.

(1963/2007). De los nombres del padre. Buenos Aires: Paidós.

(1971/2009). O Seminário, Livro 18: de um discurso que não fosse semblante.

Rio de Janeiro: Jorge Zahar.

(1972-73/2006). O Seminário, Livro 20: Aún. Buenos Aires: Paidós.

LAMBOTTE, M. C. (1996). "Psicanálise e Música”, in KAUfMAN, P. Dicionário de Psicanálise. Rio de Janeiro: Jorge Zahar.

LASNIK, M.; MAESTRO, S.; MURATORI, F. et. al. (2005). "Interações sonoras entre bebês que se tornaram autistas e seus pais”, in Proceedings of the Colóquio franco-brasileiro sobre a clínica com bebês. Disponível em: http://www.proceedings.scielo.br/scielo.php?script=sci_arttext\& $\mathrm{pid}=\mathrm{MSC} 0000000072005000100004 \& \operatorname{lng}=\mathrm{en} \& \mathrm{nrm}=$ iso. Acesso em $7 / 2 / 2010$.

ROUSSEAU, J. J. (1781/1997). “Ensaio sobre a origem das línguas: no qual se fala da melodia e da imitação musical”, in Coleção Os Pensadores, v.1. São Paulo: Nova Cultural. 
VIVES, J. M. (2009). Para introduzir a questão da pulsão invocante, Revista Latinoamericana de Psicopatologia Fundamental, v.12, n.2. São Paulo, p.329-341.

WISNIK, J. M. (1999). O som e o sentido: uma outra história das músicas. São Paulo: Companhia das Letras.

Carolina Mousquer Lima

carolinamlima@hotmail.com

Maria Cristina Poli

mcrispoli@terra.com.br 